Volume 13

Issue 1 Revisiting the Life and Work of Raphaël

Lemkin

Article 16

4-2019

\title{
Review: Humanitarians at War: The Red Cross in the Shadow of the Holocaust
}

Mark R. Gudgel

Omaha North High Magnet School

Follow this and additional works at: https://digitalcommons.usf.edu/gsp

\section{Recommended Citation}

Gudgel, Mark R. (2019) "Review: Humanitarians at War: The Red Cross in the Shadow of the Holocaust," Genocide Studies and Prevention: An International Journal: Vol. 13: Iss. 1: 189-190.

DOI:

https://doi.org/10.5038/1911-9933.13.1.1659

Available at: https://digitalcommons.usf.edu/gsp/vol13/iss1/16

This Book Review is brought to you for free and open access by the Open Access Journals at Digital Commons @ University of South Florida. It has been accepted for inclusion in Genocide Studies and Prevention: An International Journal by an authorized editor of Digital Commons @ University of South Florida. For more information, please contact digitalcommons@usf.edu. 


\title{
Book Review: Humanitarians at War: The Red Cross in the Shadow of the Holocaust
}

\author{
Mark R. Gudgel \\ Omaha North High Magnet School \\ Omaha, Nebraska, USA
}

Humanitarians at War: The Red Cross in the Shadow of the Holocaust

Gerald Steinacher

Oxford, Oxford University Press, 2017

330 Pages; Price: \$32.95 Hardcover

Reviewed by Mark Gudgel

Omaha North High Magnet School

"Promise me. Promise me you will never be just a bystander." Thus begins this work on the most famous aid organization in the world, on an unnumbered page immediately preceding the table of contents. The words are those not of the author, but of a Dutch Holocaust survivor, Lou Leviticus (memoirs published under the pseudonym "Ben Wajikra" - "son of Leviticus"), who lived in the same small city in Nebraska, Lincoln, where the author of this book is a professor of history. And the words were spoken not to representatives of the Red Cross, though they most certainly could have been, but rather, to a group of students gathered to hear Leviticus share his story of survival. Lou Leviticus spent the last two decades of his life sharing his story of survival with students across the state of Nebraska, his message never straying far from the role he hoped young people would play in preventing future atrocities. His parents, Max and Sara, had been murdered in Auschwitz. Leviticus passed away in 2015, but not before he and Gerald Steinacher became well acquainted.

Such a quotation is a fitting start for a work about an organization whose failures during the Holocaust are well-documented, authored by one of the finest scholars of our time for an audience far more broad in scope than many academics endeavor to approach. Humanitarians at War: The Red Cross in the Shadow of the Holocaust is an important book for its well-researched and highly nuanced examination of the role that the Red Cross, which is often rightfully criticized for being complicit or, in the very least, complacent, during World War II, played during and, far more so, immediately after the era of the Holocaust. It is a text that is equally intricate and accessible, a well-written chronology that flows seamlessly through the first half of the twentieth century, year to year and page to page, providing necessary back story about the founding of the Red Cross and the organization's role in The Great War, and introducing the reader to central figures in the Red Cross such as Max Huber, who was the president of the International Committee of the Red Cross (ICRC) from 1928 to 1944, and Huber's successor, Jacob Burckhardt, who served as president until 1948 , shortly prior to the most recent Geneva Conventions.

It is to the post-war legacy of the Red Cross that Steinacher's work is most deeply devoted. The bulk of the book focuses not on the relatively well-known and for the most part undisputed acquiescence of the ICRC to Nazi wishes during the reign of the Third Reich in Europe, the failures of the world's farthest reaching aid organization to prevent "man's inhumanity toward man," but on the aftermath of the war once the Nazis were out of power and, as Steinacher frames it, the big questions of 1945, "would the humanitarianism of the 19th century still have a place in the postwar world? Would the 'moral conscience' of the world have a future after Auschwitz?"1 Steinacher explains that the atrocities of the Nazis were as much a challenge to the philosophical foundations of the Red Cross as they were a shocking realization to the world. Could the Red Cross have a future in the world after Nazi barbarism, was a very real question complicated by the role of the German Red Cross, whose president was SS Obergruppenfuhrer Ernst Robert Grawitz, and the extreme lack of credibility that now plagued the organization.

${ }^{1}$ Gerald Steinacher, Humanitarians at War: The Red Cross in the Shadow of the Holocaust (Oxford: Oxford University Press, 2017), 84 . 
Throughout the pages of the book a picture unfolds that helps the reader to understand how the ICRC navigated infighting and division in the aftermath of a genocide during which their leadership remained notoriously silent and inactive. Moreover, with skillful work in multiple languages, Steinacher is able to convey to readers how various branches of the Red Cross maneuvered and, at times, careened through this tumultuous time period differently in different places in the world. The international dialogue that sprung from this struggle, as well as the limits and possibilities of humanitarian intervention in times of war and genocide, becomes central to the text. Steinacher seemingly also draws on his experience writing Nazis on the Run, ${ }^{2}$ a previous work, in examining the further potential damage to the reputation of the ICRC and the Vatican as Nazi war criminals fled Europe via Italy, and the desire of the United States to focus instead on other issues, not least the Cold War and the reform of the Geneva Conventions. ${ }^{3}$

It is in the most recent iteration of the Geneva Conventions where Humanitarians at War reaches a crescendo of sorts, a point at which without showing unfair and unnecessary favoritisms Steinacher lays out an historical narrative that puts the aftermath of WWII into new light. The positive results of the 1949 conferences in Geneva, Steinacher points out, could not defend against the new threat of nuclear war, but were instead "a reaction to past shortcomings and omissions." 4 Regardless, as residents of 2019, it should be difficult not to marvel at the fact that there has been no nuclear war since WWII, and no World War III to date, and this is surely due at least in part to the efforts of those in Geneva at this time, the ICRC, and to the recognition by the rest of the world of the failures of the Second World War. For all of our shortcomings and rifts, there seems to be some degree of human solidarity nevertheless, even betwixt mortal enemies. Steinacher mentions that the new Geneva Conventions took effect in 1950, and that the Soviets ratified them in 1954, followed closely in 1955 by the United States. Then, perhaps with a note of pride, he adds that "As of the writing of this book, 194 countries have ratified the Geneva Conventions, in other words, all states on this planet." 5 Perhaps the greatest victory of this book is its factual impartiality; Steinacher neither excuses the Red Cross for its failures during WWII nor downplays the immense importance of the organization's contributions to the world in which we all now live.

In an earlier section of the book titled "The Guardians of Humanity Had Failed", Steinacher fittingly quotes a letter by a Viennese Jewish Lawyer named Siegfried Kantor, published in a timely manner in Jewish Frontier in May of 1945. In this letter, Kantor leads with an almost prophetic right hook to the jaw of the ICRC:

"When future historians are able to analyze the circumstances which made possible the annihilation of one-third of the Jewish people-the bulk of European Jewry-as well as the barbarous slaughter of untold masses of other civilians during the Second World War, there is one set of problems which will give them the greatest difficulty: Where was the enlightened, civilized world, particularly the humane, neutral influences, while all this was going on? Where above all, was the International Red Cross Committee?"6

Gerald Steinacher is clearly one of those future historians Kantor was envisioning, and Humanitarians at War is as well done an analysis as Kantor could ever have hoped for. Steinacher's new book is easily the most direct, fair, and thorough treatment of this topic to date. This is a book that the armchair historian will enjoy just as much as the one in the ivory towers of academia, an important text that contributes much-needed research and far better-nuanced understandings of the reformation of the ICRC and its contributions to the post Second World War era than any had previously endeavored to write.

\footnotetext{
${ }^{2}$ Gerald Steinacher, Nazis on the Run: How Hitler's Henchmen Fled Justice (Oxford: Oxford University Press, 2011).

${ }^{3}$ Ibid., 210.

${ }^{4}$ Ibid., 234.

${ }^{5}$ Steinacher, Humanitarians at War, 234.

${ }^{6}$ Ibid., 90.
} 